\title{
Serotonin Reuptake Inhibitors Vs. Tricyclics in Deficit syndrome of Schizophrenia
}

\author{
Saeed Shoja Shafti* \\ Professor of Psychiatry, University of Social Welfare and Rehabilitation Sciences (USWR), Iran
}

Submission: June 08, 2018; Published: September 11, 2018

*Corresponding author: Saeed Shoja Shafti, MD , Professor of Psychiatry, University of Social Welfare and Rehabilitation Sciences (USWR), Razi Psychiatric Hospital, Tehran - Iran , Postal Code: 18669-58891, P.O. Box: 18735-569, Tel: 0098-21-33401220; Fax: 0098-21-33401604;

E-mail: ssshafti@gmail.com

Abstract

Introduction: Negative symptoms are essential barricades against psychosocial rehabilitation in schizophrenia. In this regard a variety of adjunctive medications have been used in different studies for improvement of these symptoms. In the present study effectiveness of tricyclics (Clomipramine, Nortriptyline, Maprotiline) has been compared with serotonin reuptake inhibitors (Citalopram, Fluoxetine, Fluvoxamine) concerning amelioration of negative symptoms.

Materials and Method: 135 schizophrenic patients were divided into three different groups, and the aforesaid adjuvant drugs were examined in three double-blind clinical controlled trials. Scale for Assessment of Negative Symptoms was used as the primary outcome measure for assessment of negative symptoms. Data were analyzed by $\mathrm{z}$ and chi-square $\left(\mathrm{X}^{2}\right.$-test) formula.

Results: Clomipramine and Nortriptyline reduced the severity of negative symptoms in some cases to a greater degree than in comparison with serotonin reuptake inhibitors ( $40 \%$ versus $20 \%$ reduction from baseline). Also, a greater number of patients benefited by tricyclics (73.33\%) in compare with the other group (65.90\%). No important side effect or worsening of positive symptoms was evident in the patients during the assessments.

Conclusion: As adjuvant medications in improvement of negative symptoms, tricyclics seem to be more effective than serotonin reuptake inhibitors.

Keywords: Schizophrenia; Negative Symptoms; Deficit Syndrome; Antidepressant; Tricyclic; Serotonin Reuptake Inhibitor.

\section{Introduction}

Negative symptoms in schizophrenia include

i. $\quad$ Restricted up to flat affect,

ii. Apathy,

iii. Alogia,

iv. Anhedonia,

v. Avolition,

vi. Asociality $[1,2]$.

Existence of at least two of these symptoms for a duration not less than twelve months is enough for diagnosis of deficit syndrome, as a subtype of schizophrenia [3]. In DSM-5, too, negative symptoms in addition to one of the major positive symptoms (delusion, hallucination, disorganized speech) for at least one month is enough for diagnosis of acute phase of schizophrenia. On the other hand, anxiety, suspiciousness, mental retardation, depression, Parkinsonism and lack of environmental stimulants can result in secondary negative symptoms or reinforcement of primary ones.
The importance of negative symptoms can be deduced, also, from the hidden firm barrier due to them between patients and others around them. Inaccessibility to patients which is resulted from such cluster of symptoms, after suppression of positive symptoms, can make different psychosocial interventions, which are employed in the framework of community psychiatry, futile. This phenomenon especially in developing or nondeveloped countries can result easily to a kind of pessimistic and doubtful standpoints regarding the goals and efficiency of rehabilitative programs. Therefore, improvement of negative symptoms by pharmacological approaches may facilitate the attainment of short-term and long-term goals of psychiatric rehabilitation. Accordingly, a series of studies had been done for comparing the effectiveness of adjunctive medications on severity of negative symptoms.

\section{Method and Materials}

RAZI Psychiatric Hospital, located in Tehran - Iran, the largest psychiatric hospital in the Middle East, and the first established centre for handling psychiatric problems since last century, had been chosen as our field for research. In summer 
of 2003, among one thousand and two hundred (1200), 270 patients with diagnosis of schizophrenia, according to the DSM IV-TR criteria, had been chosen randomly for a survey regarding the prevalence of negative symptoms and their severity. In this regard some of the patients had been excluded due to some intervening factors (Table 1). This cluster of symptoms had been estimated and registrated by Scale for Assessment of Negative Symptoms (SANS) [4]. After determining the prevalence, they had been divided into three different groups. Group A $(n=30)$ for a Clinical Controlled Trial (CCT) regarding the effectiveness of Clomipramine and Citalopram on reducing the severity of negative symptoms.

Table 1: Inclusion and Exclusion criteria.

\begin{tabular}{|l|c|}
\hline Inclusion criteria & Exclusion criteria \\
\hline \multirow{4}{*}{ Schizophrenia } & Depression \\
\cline { 2 - 3 } & Schizoaffective \\
\cline { 2 - 3 } & Mental retardation \\
\cline { 2 - 3 } & Bipolar disorders \\
\cline { 2 - 3 } & Ueurological disorders \\
\cline { 2 - 3 } & Using atypical antipsychotics \\
\cline { 2 - 3 } & Medical complications \\
\cline { 2 - 3 } & Unstable, irritable, aggressive patients \\
\cline { 2 - 3 } & Duration less than one year \\
\cline { 2 - 3 } & Parkinsonism \\
\cline { 2 - 3 } & Medical deafness or muteness \\
\hline
\end{tabular}

Groups B $(n=75)$ with a similar approach with respect to the effectiveness of Fluoxetine and Nortriptyline, and finally group $\mathrm{C}$ $(n=30)$ regarding similar effects of Fluvoxamine and Maprotiline. In every group and at

the beginning of the related trials, before adding any adjunctive medication, a new estimation of the negative symptoms by SANS had been performed as the baseline and then the adjunctive drugs had been added to the patient's current treatments, including typical antipsychotics (one of the Chlorpromazine, haloperidol, Perphenazine, Trifluperazine or Fluphenazine decanoate). Each drug in each group was started with the lower dose and then at the end of the third week after beginning adjunctive treatments, again another estimating of negative symptoms by SANS had been performed. Then the dosage of the aforesaid drugs had been doubled and after another three weeks the final severity of negative symptoms and their response had been registered. Overall grade 1, 2 and 3 were regarded as non-severe (mild) symptoms and grade 4 and 5 as severe. At the end, data had been analyzed by $\mathrm{Z}^{1}$ and chi-square ( $\mathrm{X}^{2}$-test) formula. All of the controlled trials had been done in a double-blind fashion and by the same team.

Interview with the patients and their relatives, and also observations by staff, social workers, psychologists and occupational therapists had provided the necessary resources for this research.

\section{Results}

The prevalence of negative symptoms among schizophrenic patients was remarkable. Almost no patient was free from negative symptom, and no specific or similar pattern could be found among them. Although some of the patients had similar severity in all of their negative symptoms, but many of them had discrete symptoms with different severity. The prevalence of Affecting Blunting, Alogia, Avolition-Apathy, AnhedoniaAsociality and finally Attention Deficit among this sample $(n=270)$ were: \%96/28 ( $n=260), \% 94 / 80 \quad(n=156), \% 99.62$ $(n=269), \% 98.88(n=267)$ and \%99.25 (n=268), respectively.

$$
\begin{aligned}
& 1-z=\frac{\frac{x_{1}}{n_{1}}-\frac{x_{2}}{n_{2}}}{\sqrt{p(1-p)\left(\frac{1}{n_{1}}+\frac{1}{n_{2}}\right)}}, p=\frac{x_{1}+x_{2}}{n_{1}+n_{2}}, \alpha=0.05, \\
& |z|>z_{1}-\frac{\alpha}{2}=(0.975)=1.96
\end{aligned}
$$

Table 2: Prevalence of Negative symptoms among 270 schizophrenic

\begin{tabular}{|c|c|c|c|c|c|c|}
\hline Severity & \multirow{3}{*}{\multicolumn{2}{|c|}{ Normal }} & \multirow{3}{*}{\multicolumn{2}{|c|}{$\begin{array}{c}\text { Mild Grade } \\
\qquad 1,2,3 \\
\text { SANS }\end{array}$}} & \multirow{3}{*}{\multicolumn{2}{|c|}{$\begin{array}{c}\text { Severe Grade } \\
\text { 4, } 5 \text { SANS }\end{array}$}} \\
\hline Negative & & & & & & \\
\hline Symptoms & & & & & & \\
\hline Affective Blunting & 10 & $\% 3.72$ & 160 & $\% 59.25$ & 100 & $\% 37.03$ \\
\hline Alogia & 14 & $\% 5.20$ & 155 & $\% 57.40$ & 101 & $\% 37.40$ \\
\hline Avolition-Apathy & 1 & $\% 0.38$ & 171 & $\% 63.33$ & 98 & $\% 36.29$ \\
\hline Anhedonia-Isolation & 3 & $\% 1.12$ & 144 & $\% 53.33$ & 123 & $\% 45.55$ \\
\hline Attention Deficit & 2 & $\% 0.75$ & 115 & $\% 42.59$ & 153 & $\% 56.66$ \\
\hline
\end{tabular}
patients in Razi Psychiatric Hospital.

(Table 2) The age of these patients were between 24-68 years (mean=43.6) and the duration of their residency in hospital was between 2.5-28 years (mean=17.83) and all of them were male. In the first trial, as group A, ten patients were included in every subgroup. The starting dose was $20 \mathrm{mg}$, and $25 \mathrm{mg}$ for Citalopram and Clomipramine, respectively, which were doubled after three weeks. According to the resulted data, Citalopram $(\mathrm{p}<0 / 001)$ and Clomipramine $(\mathrm{p}<0 / 01)$ were more effective than placebo in reducing the severity of negative symptoms. This difference was not large between them themselves $(p<0.25)$. The reduction in severity was restricted to $20 \%$ from baseline, and a $40 \%$ reduction was seen in Alogia and Attention Deficit in two separate patients by Clomipramine. No kind of relationship was evident between response and the severity of the symptoms (Figure 1).

Only one patient in every subgroup except placebo, showed $20 \%$ reduction in severity of all of their negative symptoms. Affective Blunting showed the most and Anhedonia-Asociality the least response in this group (Table 3) (Figure 1).

In second trial seventy-five patients had been divided into three subgroups. Fluoxetine and Nortiptyline had been started with $20 \mathrm{mg}$ and $25 \mathrm{mg}$ daily, respectively. One patient in the Fluoxetine subgroup, due to his inclination and one in the 


\section{Global Journal of Intellectual \& Developmental Disabilities}

placebo subgroup due to cardiac infarction were omitted from the trial. After three weeks the aforesaid dosages doubled. $37.5 \%$ $(\mathrm{n}-9), 62.5 \%(\mathrm{n}=15)$, and $80 \%(\mathrm{n}=20)$ of patients showed $20 \%$ reduction in the severity of some of their negative symptoms by placebo, Fluoxetine and Nortriptyline, respectively, at the end of Table 3: Response of participants in the first trial. the trial. Only three cases in the Nortiptyline group showed $40 \%$ improvement of negative symptoms. There was no difference between mild or severe symptoms regarding their response to the adjunctive drugs.

\begin{tabular}{|c|c|c|c|c|c|c|c|c|c|c|c|c|}
\hline \multirow{2}{*}{$\begin{array}{c}\begin{array}{c}\text { Negative } \\
\text { Symptoms }\end{array} \\
\text { Drugs }\end{array}$} & \multicolumn{2}{|c|}{$\begin{array}{l}\text { Affecting } \\
\text { Blunting }\end{array}$} & \multicolumn{2}{|c|}{ Alogia } & \multicolumn{2}{|c|}{ Avolition Apathy } & \multicolumn{2}{|c|}{$\begin{array}{l}\text { Anhedonia } \\
\text { Asociality }\end{array}$} & \multicolumn{2}{|c|}{ Attention Deficit } & \multicolumn{2}{|c|}{ Total } \\
\hline & $\begin{array}{l}\text { No. of } \\
\text { patient }\end{array}$ & Percent & $\begin{array}{l}\text { No. of } \\
\text { patient }\end{array}$ & Percent & $\begin{array}{l}\text { No. of } \\
\text { patient }\end{array}$ & Percent & $\begin{array}{c}\text { No. of } \\
\text { patient }\end{array}$ & Percent & $\begin{array}{l}\text { No. of } \\
\text { patient }\end{array}$ & Percent & $\begin{array}{l}\text { No. of } \\
\text { patient }\end{array}$ & Percent \\
\hline $\begin{array}{l}\text { Fluoxetine } \\
20-40 \mathrm{mg}\end{array}$ & 4 & $16.6 \%$ & 4 & $16.6 \%$ & 7 & $29.1 \%$ & 2 & $8.3 \%$ & 10 & $41.6 \%$ & $15 / 24$ & $62.5 \%$ \\
\hline $\begin{array}{l}\text { Nortriptyline } \\
25-50 \mathrm{mg}\end{array}$ & 6 & $24 \%$ & 9 & $36 \%$ & 8 & $32 \%$ & 9 & $36 \%$ & 10 & $40 \%$ & $20 / 25$ & $80 \%$ \\
\hline Placebo & 2 & $8.3 \%$ & 6 & $25 \%$ & 1 & $4.1 \%$ & 4 & $16.6 \%$ & 6 & $25 \%$ & $9 / 24$ & $37.5 \%$ \\
\hline
\end{tabular}

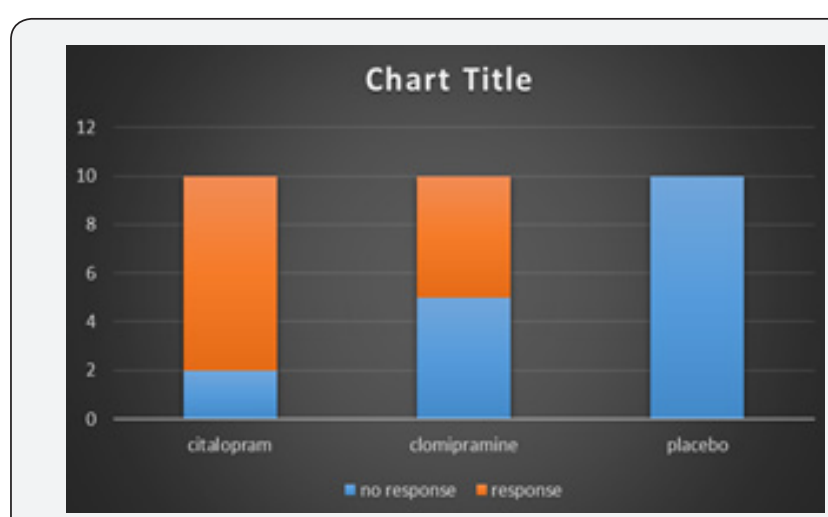

Figure 1: Improvement of negative symptoms in the $1^{\text {st }}$ trial.

In comparing with placebo, Nortriptyline was remarkably more effective $(\mathrm{P}<0.005)$. But regarding Fluoxetine it was not so $(p<0.1)$. Attention Deficit responded more frequently to the adjunctive drugs and Affecting Blunting less than others. Only in one patient in the Nortriptyline subgroup all of the negative symptoms showed improvement (Table 4) (Figure 2).

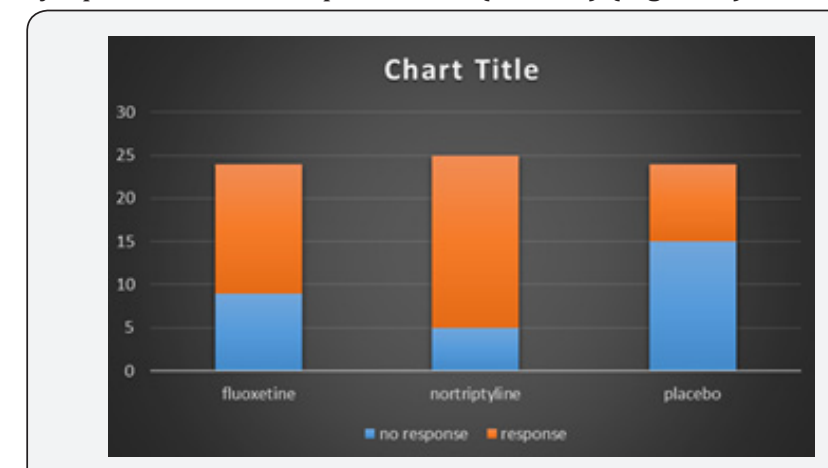

Figure 2: Improvement of negative symptoms in the $2^{\text {nd }}$ trial.

Table 4: Response of participants in the second trial.

\begin{tabular}{|c|c|c|c|c|c|c|c|c|c|c|c|c|}
\hline \multirow{2}{*}{$\begin{array}{c}\begin{array}{c}\text { Negative } \\
\text { Symptoms }\end{array} \\
\text { Drugs }\end{array}$} & \multicolumn{2}{|c|}{$\begin{array}{l}\text { Affecting } \\
\text { Blunting }\end{array}$} & \multicolumn{2}{|c|}{ Alogia } & \multicolumn{2}{|c|}{ Avolition Apathy } & \multicolumn{2}{|c|}{$\begin{array}{l}\text { Anhedonia } \\
\text { Asociality }\end{array}$} & \multicolumn{2}{|c|}{ Attention Deficit } & \multicolumn{2}{|c|}{ Total } \\
\hline & $\begin{array}{l}\text { No. of } \\
\text { patient }\end{array}$ & Percent & $\begin{array}{l}\text { No. of } \\
\text { patient }\end{array}$ & Percent & $\begin{array}{l}\text { No. of } \\
\text { patient }\end{array}$ & Percent & $\begin{array}{l}\text { No. of } \\
\text { patient }\end{array}$ & Percent & $\begin{array}{l}\text { No. of } \\
\text { patient }\end{array}$ & Percent & $\begin{array}{l}\text { No. of } \\
\text { patient }\end{array}$ & Percent \\
\hline $\begin{array}{c}\text { Citalopram 20- } \\
40 \mathrm{mg}\end{array}$ & 5 & $50 \%$ & 4 & $40 \%$ & 4 & $40 \%$ & 3 & $30 \%$ & 4 & $40 \%$ & $8 / 10$ & $80 \%$ \\
\hline $\begin{array}{l}\text { Clomipramine } \\
25-50 \mathrm{mg}\end{array}$ & 4 & $40 \%$ & 2 & $20 \%$ & 1 & $10 \%$ & 3 & $30 \%$ & 3 & $30 \%$ & $5 / 10$ & $50 \%$ \\
\hline Placebo & 0 & $0 \%$ & 0 & $0 \%$ & 0 & $0 \%$ & 0 & $0 \%$ & 0 & $0 \%$ & $0 / 10$ & $0 \%$ \\
\hline
\end{tabular}

In the third trial, another thirty (30) patients were divided into three subgroups and $25 \mathrm{mg}$ Maprotiline, $50 \mathrm{mg}$ Fluvoxamine, and placebo were added as adjunctive medications to their current antipsychotic drugs, respectively. After three weeks these dosages doubled. At the end, \%80 (n=8), 60\% (n=6), and $20 \%(n=2)$ of cases showed 20\% improvement in some of their negative symptoms under the influence of Maprotiline, Fluvoxamine and placebo respectively (Table 5). While this effect was significant for Maprotiline, in comparing with placebo $(\mathrm{p}<0.01)$, it was not so for Fluvoxamine $(\mathrm{p}<0.1)$.

In this sample severe symptoms responded more than mild ones to adjunctive medications (Table 5) (Figure 3).

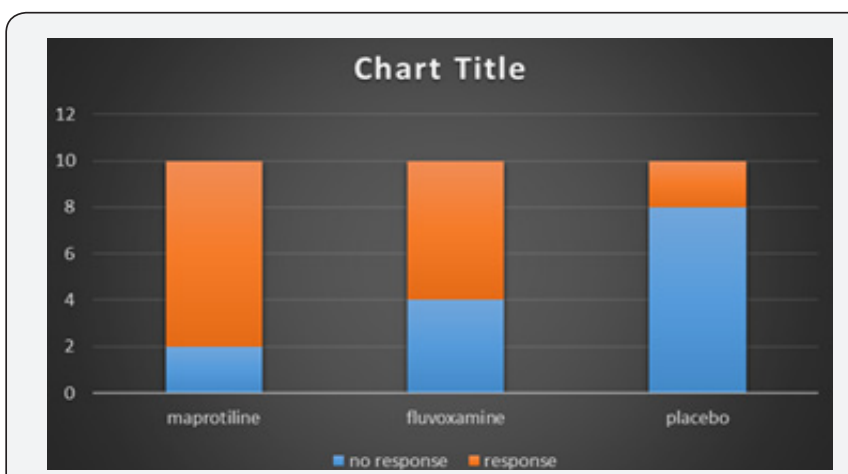

Figure 3: Improvement of negative symptoms in the $3^{\text {rd }}$ trial. 


\section{Global Journal of Intellectual \& Developmental Disabilities}

Table 5: Response of participants in the third trial.

\begin{tabular}{|c|c|c|c|c|c|c|c|c|c|c|c|c|}
\hline \multirow{2}{*}{$\begin{array}{c}\begin{array}{c}\text { Negative } \\
\text { Symptoms }\end{array} \\
\text { Drugs }\end{array}$} & \multicolumn{2}{|c|}{$\begin{array}{l}\text { Affecting } \\
\text { Blunting }\end{array}$} & \multicolumn{2}{|c|}{ Alogia } & \multicolumn{2}{|c|}{ Avolition Apathy } & \multicolumn{2}{|c|}{$\begin{array}{l}\text { Anhedonia } \\
\text { Asociality }\end{array}$} & \multicolumn{2}{|c|}{ Attention Deficit } & \multicolumn{2}{|c|}{ Total } \\
\hline & $\begin{array}{l}\text { No. of } \\
\text { patient }\end{array}$ & Percent & $\begin{array}{l}\text { No. of } \\
\text { patient }\end{array}$ & Percent & $\begin{array}{l}\text { No. of } \\
\text { patient }\end{array}$ & Percent & $\begin{array}{l}\text { No. of } \\
\text { patient }\end{array}$ & Percent & $\begin{array}{l}\text { No. of } \\
\text { patient }\end{array}$ & Percent & $\begin{array}{l}\text { No. of } \\
\text { patient }\end{array}$ & Percent \\
\hline $\begin{array}{l}\text { Maprotiline 25- } \\
\quad 50 \mathrm{mg}\end{array}$ & 3 & $30 \%$ & 5 & $50 \%$ & 0 & $0 \%$ & 5 & $50 \%$ & 3 & $30 \%$ & $8 / 10$ & $80 \%$ \\
\hline $\begin{array}{l}\text { Fluvoxamine } 50- \\
100 \mathrm{mg}\end{array}$ & 5 & $50 \%$ & 3 & $30 \%$ & 1 & $10 \%$ & 3 & $30 \%$ & 1 & $10 \%$ & $6 / 10$ & $60 \%$ \\
\hline Placebo & 0 & $0 \%$ & 2 & $20 \%$ & 0 & $0 \%$ & 1 & $10 \%$ & 0 & $0 \%$ & $2 / 10$ & $20 \%$ \\
\hline
\end{tabular}

\section{Discussion}

Effectiveness of adjunctive medications in reducing the severity of Negative symptoms is remarkable. In the previous studies by Linden Mayer (1990-1993), positive effects of Clomipramine had been stressed [5- 7]. Our findings, also, are in harmony with aforesaid results. Clomipramine showed more efficacies with respect to Affective Blunting. But regarding to Citalopram, Silver (2001) had reported negative results, like Sertraline, and the other studies had focused more on its positive effects on the treatment of depressive schizophrenic patients. But in the present assessment, the higher effectiveness of Citalopram in comparing with Clomipramine is fascinating, since it's side effects and pharmacokinetic interactions in comparing with tricyclics are more safe and tolerable. But On the other hand, it was only with the Clomipramine that a $40 \%$ reduction of severity of Negative symptoms was evident.

Regarding effectiveness of Fluoxetine, it's positive effects had been reported by Silver (1992), Coff (1991) and Linden Mayer [5]. According to our findings, Fluoxetine was more effective than placebo in reducing the severity of negative symptoms and its most effect was on Avolition - Apathy, and its least effect was on Anhedonia - Asociality. With respect to Nortriptyline, which showed the most positive effect is our second trial, though there were positive reports about Imipramine by Siris (1990), Mianserin, Mizoky (1992) and Amitriptyline by Prusof (1989), but we did not find any research regarding the effectiveness of Nortriptyline on negative symptoms. According to our findings, Nortriptyline was remarkably more effective than placebo $(\mathrm{p}<0.005)$ and Fluoxetine, and its most efficacy was evident with respect to Attention Deficit. In addition, it was only the Nortriptyline that could reduce the severity of Negative symptoms up to $40 \%$ in three patients. Regarding Maprotiline and Fluvoxamine, our findings were similar to Yamagami (1989) and Silver (1992) respectively [5]. The most influence of Maprotiline was evident with regard to Alogia and Anhedonia - Asociality, and regarding fluvoxamine, it was on Affective Blunting. In general, tricyclics (TCAs) improved Negative symptoms in 73.33 $\%(n=33)$ of cases, while this was around $65.90 \%(n=29)$ for serotonin reuptake inhibitors (SRIs).

Larger and stronger effect of TCAs in comparing with SRIs in the current assessment is in harmony with recently increasing similar findings in literature regarding its stronger effect on severe or melancholic major depressive disorder,
Arana (2000). Modulating effect of dopamine afferents on sensitivity of cortical post-synaptic Beta-adrenergic receptors, influence of noradrenergic neurons in controlling the sensitivity of cortical D1 receptors and inhibition of cortical transmission at D1 receptor via stimulation of cortical Alpha1-adrenergic receptors, Tassin (1992), and the relationship between serum level of Norepinephrine and Negative symptoms ( their direct relationship in acute phase of the illness and reverse one in chronic phase) demonstrate the interplay between Noradrenergic transmission and presentation of Negative symptoms in schizophrenia $[6,7]$.

The nor-epinephrine re-uptake blocking effect of TCAs (especially Nortriptyline and Maprotiline in comparing with Clomipramine) in addition to their $5 \mathrm{HT}$ re-uptake blocking effect (especially Clomipramine and, to a lesser extent, Nortriptyline) at least theoretically make them more powerful than SRIs, which only block re-uptake of 5HT. Neither of patients in our aforesaid trials had suffered any important side effects of adjunctive drugs and none of them had showed any worsening of positive symptoms, due to appropriate antipsychotic coverage prior to trials. Maybe longer duration and higher dosage of adjunctive drugs could result in better response in this regard.

\section{Conclusion}

As adjuvant medications in improvement of negative symptoms, tricyclics seem to be more effective than serotonin reuptake inhibitors.

\section{References}

1. Thomas H Meglashan, Wayne S Fention (1994) The Positive-Negative distinction in schizophrenia. DSM IV source book, Chapter 25: 381391.

2. Nancy Andreasen, Micheal Falbum (1994) Characteristic symptoms of schizophrenia. DSM IV source Book, Chapter 22: 365-380.

3. W Carpenter (1997) Pharmacotherapy of schizophrenia, Negative symptoms; Supplement to the Am J psychiatry 154(4).

4. Kaplan Sadock (2003) Classification in psychiatry and psychiatric rating scales. Synopsis of Psychiatry 288-318.

5. Robert W Buchanan, Martin Brandes, Alan Breier (1996) Treating Negative symptoms: pharmacological strategies. The new pharmacotherapy of schizophrenia 179-197.

6. John F Greden, Rajive Tandon (1991) Negative schizophrenic symptoms.

7. Herbert Meltzer (1991) Pharmacologic treatment of Negative symptoms, Negative schizophrenic symptoms, pp. 215-231. 
(C) This work is licensed under Creative Commons Attribution 4.0 License

DOI: 10.19080/GJIDD.2018.05.555657

\section{Your next submission with Juniper Publishers} will reach you the below assets

- Quality Editorial service

- Swift Peer Review

- Reprints availability

- E-prints Service

- Manuscript Podcast for convenient understanding

- Global attainment for your research

- Manuscript accessibility in different formats

( Pdf, E-pub, Full Text, Audio)

- Unceasing customer service

Track the below URL for one-step submission https://juniperpublishers.com/online-submission.php 